\title{
PERBANDINGAN KADAR FLAVONOID DAN FENOLIK TOTAL EKSTRAK METANOL DAUN BELUNTAS (Pluchea indica L.) PADA BERBAGAI METODE EKSTRAKSI
}

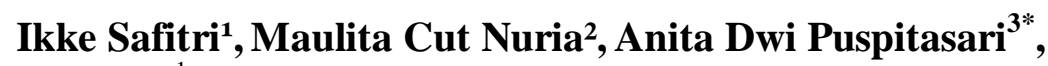 \\ ${ }^{1}$ Fakultas Farmasi, Universitas Wahid Hasyim \\ Jl. Menoreh Tengah X/22, Sampangan, Semarang 50236. \\ "Email: anita@unwahas.ac.id
}

\begin{abstract}
Abstrak
Beluntas (Pluchea indica L.) merupakan tumbuhan yang mengandung sterol, flavonoid, tanin, dan fenol hidrokuinon. Flavonoid dan fenolik dapat diekstraksi dengan metode perkolasi, maserasi, soxhlet, dan refluks. Penelitian ini bertujuan untuk membandingkan kadar flavonoid dan fenolik total ekstrak metanol daun beluntas (EMDB) pada berbagai metode ekstraksi.

Penentuan kadar flavonoid dan fenolik total dilakukan secara spektrofotometri. Pereaksi $\mathrm{AlCl}_{3}$ dan Folin-ciocalteu digunakan pada metode spektrofotometri tersebut dengan senyawa pembanding kuersetin dan asam galat. Seri konsentrasi kuersetin adalah 5, 10, 15, 20 dan $25 \mu \mathrm{g} / \mathrm{mL}$ pada $\lambda=428,90 \mathrm{~nm}$ dengan operating time 30 menit. Persamaan kurva baku yang diperoleh adalah $y=0,02001 x+$ 0,10906 ( $x=$ kadar flavonoid dalam $\mu \mathrm{g} / \mathrm{mL}, y=$ absorbansi) dengan nilai $r=0,99848$. Serial konsentrasi asam galat adalah 10, 20, 30, 40 dan $\quad 50 \mu \mathrm{g} / \mathrm{mL}$ pada $\lambda=$ $757,80 \mathrm{~nm}$ dengan operating time 2 jam. Persamaan kurva bakunya adalah $y=0,01086$ $x+0,12030$ ( $x=$ kadar fenolik dalam $\mu \mathrm{g} / \mathrm{mL}, y=$ absorbansi) dengan nilai $r=0,99808$. Kadar flavonoid dan fenolik total EMDB dari berbagai metode ekstraksi dianalisis statistik One-Way Anova kemudian dilanjutkan uji Bonferroni pada taraf kepercayaan $95 \%$.

Hasil penelitian menunjukkan kadar flavonoid total EMDB dengan metode perkolasi, maserasi, soxhlet dan refluks berturut-turut sebesar 66,75; 51, 80 ; 47,72 dan 38,39 mg/gram ekstrak. Adapun kadar fenolik total berturut-turut sebesar 116,95; 84,11; 67,53 dan 44,36 mg/gram ekstrak. Hasil statistika menunjukkan adanya perbedaan bermakna pada kadar flavonoid dan fenolik total EMDB diantara berbagai metode ekstraksi.
\end{abstract}

Kata kunci: ekstraksi, fenolik, flavonoid

\section{PENDAHULUAN}

Tanaman Beluntas (Pluchea indica L.) termasuk family Asteraceae yang telah dimanfaatkan sebagai pangan dan obat tradisional. Beluntas merupakan salah satu jenis tanaman yang sudah lama dikenal dan ditanam di Indonesia. Pemanfaatan bagian dari tanaman seperti akar, batang, daun, bunga, kulit dan buah digunakan sebagai obat (Depkes RI, 2008). Bioaktivitas daun beluntas antara lain sebagai antioksidan, antiinflamasi, antimikroba, antinosiceptor, antituberkulosis, antiproliferasi sel kanker, antidiare, dan antitusif (Suriyaphan, 2014).

Ekstrak metanol daun beluntas mengandung sejumlah senyawa fitokimia seperti tanin, sterol, flavonoid, dan fenol hidrokuinon (Widyawati, et al., 2010). Kandungan fitokimia daun beluntas yang telah diisolasi berupa senyawa fenolik antara lain 1,3,4,5-tetra- $O$-caffeoylquinic acid, 3,4,5-tri-Ocaffeoyl quinic acid, chlorogenic acid, dan ferulic acid (Emadeldin dan Sayed, 2013). Ekstrak metanol daun beluntas mengandung flavonoid golongan flavonol (quersetin, kaemferol, mirisetin, luteolin, apigenin) (Andarwulan, et al., 2010).

Ekstraksi simplisia dapat dilakukan dengan berbagai metode ekstraksi baik cara dingin maupun cara panas. Penelitian Damar, et al., (2014) melaporkan bahwa flavonoid dari daun kayu kapur (Melanolepsis multiglandulosa Reinch f) yang diekstraksi secara maserasi memiliki kadar lebih tinggi dibandingkan secara soxhlet. Penelitian Widyatno (2010) melaporkan bahwa flavonoid dari daun kumis kucing (Orthosiphon aristatus (BL) Miq) yang diekstraksi secara maserasi dan perkolasi memiliki kadar lebih tinggi dibandingkan secara soxhlet. Kedua penelitian 
tersebut menunjukkan bahwa flavonoid yang terdapat pada daun kayu kapur dan daun kumis kucing tidak stabil terhadap pemanasan.

Penelitian Verawati, et al., (2016) melaporkan bahwa kandungan fenolik daun pilandang (Solenostemon scutellarioides (L.) Codd) yang diekstraksi secara soxhlet memiliki kadar lebih tinggi dibandingkan maserasi. Penelitian lainnya Utami, et al., (2015) melaporkan bahwa kandungan fenolik dan flavonoid daun sukun (Artocarpus altitis fosberg) yang diekstraksi secara refluks memiliki kadar lebih tinggi dibandingkan maserasi. Hal tersebut menunjukkan bahwa kadar fenolik dan flavonoid yang terdapat dalam daun pilandang dan daun sukun stabil terhadap pemanasan. Berubahnya suhu selama proses ekstraksi mempengaruhi kelarutan suatu senyawa karena adanya pengaruh massa jenis (massa jenis sangat sensitif terhadap perubahan suhu), semakin tinggi suhu pada proses ekstraksi maka dapat mempercepat perpindahan massa dan meningkatkan hasil ekstraksi (Bimakr, et al., 2011). Berdasarkan latar belakang tersebut, maka penulis melakukan penelitian mengenai perbandingan berbagai metode ekstraksi terhadap kadar flavonoid dan fenolik total ekstrak metanol daun beluntas (Pluchea indica L.).

Penetapan kadar flavonoid total menggunakan metode spektrofotometri seperti yang dilakukan oleh Chang, et al., (2002). Prinsip metode ini adalah terbentuknya kompleks antara $\mathrm{AlCl}_{3}$ dengan flavonoid yang menghasilkan reaksi warna, sehingga terjadi pergeseran panjang gelombang ke arah visible (tampak) ditandai dengan warna larutan yang dihasilkan menjadi lebih kuning, sedangkan penambahan kalium asetat bertujuan untuk mempertahankan panjang gelombang pada daerah visible (tampak).

Penetapan kadar fenolik total dengan reagen Folin Ciocalteu berdasarkan reaksi reduksi-oksidasi (Ahmad, et al., 2015). Reagen Folin Ciocalteu (molybdotungstate) mengoksidasi gugus hidroksil $\mathrm{OH}^{-}$dari senyawa golongan fenolik membentuk kompleks senyawa berwarna biru. Senyawa fenolik bereaksi dengan reagen Folin Ciocalteu hanya dalam suasana basa, sehingga pada pengujian ditambahkan $\mathrm{Na}_{2} \mathrm{CO}_{3}$ untuk membentuk suasana basa dan reaksi dapat berjalan lebih cepat (Agustiningsih, et al., 2010).

\section{METODOLOGI}

\section{Bahan}

Daun Beluntas (Pluchea indica L.) yang digunakan pada penelitian memiliki karakteristik berwarna hijau diambil dari tumbuhan yang tumbuh di daerah Desa Talun, Kecamatan Kayen, Kabupaten Pati, Jawa Tengah. Pelarut yang digunakan terdiri dari Metanol teknis, Metanol p.a (Merck), dan aquadest. Adapun bahan lainnya adalah Kuersetin (Sigma), pereaksi $\mathrm{AlCl}_{3}$ (Merck), Kalium Asetat (Merck), reagen Folin-ciocalteu, Asam Galat (Sigma), dan $\mathrm{Na}_{2} \mathrm{CO}_{3}$.

\section{Alat}

Seperangkat alat ekstraksi yang terdiri dari maserasi, perkolasi, soxhlet, refluks dan seperangkat alat gelas (Pyrex). Alat lainnya adalah spektrofotometer UV-Vis 1800 (Shimadzu), timbangan elektrik (Ohaus), vaccum rotary evapotaror (Heidolph), mikropipet (Socorex), dan vortex (XH-B).

\section{Prosedur Penelitian}

Sebanyak $5000 \mathrm{~g}$ daun beluntas dikeringkan, diambil $1000 \mathrm{~g}$ simplisis daun belunta untuk dihaluskan dan dihasilkan $775 \mathrm{~g}$ serbuk daun beluntas. Perlakuan pertama proses yang dilakukan antara lain $100 \mathrm{~g}$ serbuk beluntas dimaserasi, disaring kemudian ampas dibuang sehingga terbentuk maserat daun beluntas, dipekatkan menggunakan rotary evaporator sehingga diperoleh ekstrak kental kemudian dianalisis kadar flavonoidnya menggunakan spektrofotometer. Melakukan cara di atas untuk variasi proses lainnya dengan perkolat, soxhlet dan refluks.

\section{HASIL DAN PEMBAHASAN \\ Determinasi Tumbuhan}

Hasil determinasi menunjukkan kunci determinasi sebagai berikut : 1b, 2b, 3b, 4b, 7b, $9 \mathrm{~b}, 10 \mathrm{~b}, 11 \mathrm{~b}, 12 \mathrm{~b}, 13 \mathrm{~b}, 14 \mathrm{~b}, 16 \mathrm{~b}, \ldots$. Golongan 11 : Tanaman dengan daun majemuk berhadapan,... 286b, 288b, 289, .............. Famili 121 : Compositae/Asteraceae, 1a, 2b, 3b, $4 \mathrm{~b}, 5 \mathrm{a}, 6 \mathrm{~b}, 8 \mathrm{~b}, 9 \mathrm{~b}, 10 \mathrm{~b}, \ldots \ldots \ldots$ Genus 8 : Pluchea ............ Spesies : Pluchea indica (L.) Less. (Beluntas).

Hasil determinasi menunjukkan bahwa tumbuhan yang digunakan dalam penelitian bener-benar tanaman beluntas. Daun beluntas diperoleh dari beberapa tumbuhan yang hidup di wilayah yang sama. Hal ini bertujuan untuk menghindari adanya perbedaan varietas 
tumbuhan, sehingga perbedaan variasi kandungan senyawa kimia tidak terlalu besar.

\section{Pembuatan Serbuk Simplisia dan Ekstrak Daun Beluntas}

Daun beluntas segar yang digunakan dalam penelitian sebanyak $\quad 5000$ gram. Setelah daun beluntas dikeringkan menghasilkan simplisia sebanyak 1000 gram dengan rendemen simplisia sebesar $20 \%$ dan kadar air simplisia sebesar 5\%. Hasil pengeringan simplisia ini dianggap baik karena kadar air dibawah 10\%, sehingga mutu simplisia terjamin. (Depkes RI, 1986). Serbuk daun beluntas yang digunakan untuk ekstraksi sebanyak 400 gram yang dibagi dalam 4 metode ekstraksi, setiap metode ekstraksi menggunakan serbuk daun beluntas sebanyak 100 gram.

\section{Pengujian Organoleptik Ekstrak}

Ekstrak daun beluntas dilakukan pengujian organoleptik untuk mendeskripsikan bentuk, warna, dan bau. Hasil Organoleptik Ekstrak Metanol Daun Beluntas dari Berbagai Metode Ekstraksi.

Tabel 1. Uji organoleptic ekstrak

\begin{tabular}{llll}
\hline Metode & \multicolumn{3}{c}{ Organoleptik } \\
\cline { 2 - 4 } Ekstraksi & Bentuk & Bau & \multicolumn{2}{c}{ Warna } \\
\hline Perkolasi & Kental & Khas & Hijau pekat kehitaman \\
Maserasi & Kental & Khas & Hijau pekat kehitaman \\
Soxhlet & Kental & Khas & Hijau pekat kehitaman \\
Refluks & Kental & Khas & Hijau pekat kehitaman \\
\hline
\end{tabular}

\section{Rendemen Ekstrak}

Hasil Rendemen Ekstrak Metanol Daun Beluntas dari Berbagai Metode Ekstraksi

Tabel 2. Rendemen

\begin{tabular}{cc}
\hline Metode Ekstraksi & $\begin{array}{c}\text { Rendemen Ekstrak } \\
(\%)\end{array}$ \\
\hline Perkolasi & 25 \\
Maserasi & 23 \\
Soxhlet & 20,9 \\
Refluks & 16,4 \\
\hline
\end{tabular}

Rendemen ekstrak yang dihasilkan dari ekstraksi metode dingin (perkolasi dan maserasi) lebih besar dibandingkan ekstraksi metode panas (soxhlet dan refluks). Hal ini dapat terjadi karena senyawa aktif dari daun beluntas lebih banyak tersari dengan metanol pada temperatur kamar. Proses ekstraksi secara perkolasi tidak terjadi kejenuhan pelarut karena pelarut diganti secara terus menerus, mulai dari warna pelarut yang semula hijau pekat menjadi jernih. Sementara itu, metode panas (soxhlet dan refluks) memberikan hasil rendemen pada metode soxhlet lebih besar dibandingkan dengan refluks, hal ini disebabkan pada metode soxhlet terjadi proses sirkulasi pelarut didalam alat soxhlet sehingga pelarut yang digunakan untuk penyarian simplisia juga selalu baru, selain itu simplisia tidak kontak langsung dengan larutan penyari yang panas.

Berdasarkan nilai rendemen ekstrak metanol daun beluntas diperoleh hasil bahwa metode perkolasi memberikan rendemen paling besar dibandingakan ketiga metode ekstraksi lainnya. Hal ini menunjukkan bahwa untuk mendapatkan rendemen ekstrak metanol daun beluntas yang paling besar dapat menggunakan metode perkolasi.

\section{Penentuan Panjang Gelombang Maksimum} Penentuan panjang gelombang maksimum dilakukan dengan mengukur absorbansi senyawa kompleks kuersetin- $\mathrm{AlCl}_{3}$ dan senyawa kompleks molibdenum-tungsten pada daerah visibel sehingga diperoleh serapan yang maksimum. Panjang gelombang maksimum yang dihasilkan akan digunakan untuk mendapatkan nilai absorbansi yang memberikan sensitivitas pengukuran tertinggi. Blangko yang digunakan untuk penetapan kadar flavonoid total adalah pelarut metanol p.a ditambah pereaksi kalium asetat dan aluminium klorida. Panjang gelombang maksimum yang diperoleh yaitu 428,90 nm. Blangko yang digunakan dalam penentuan kadar fenolik total adalah pelarut metanol p.a ditambah pereaksi folin-ciocalteu dan natrium karbonat. Panjang gelombang maksimum yang diperoleh yaitu $757,80 \mathrm{~nm}$

\section{Penentuan Operating time}

Penentuan Operating time untuk flavonoid dilakukan dengan membaca serapan senyawa kompleks kuersetin- $\mathrm{AlCl}_{3}$ konsentrasi $15 \mu \mathrm{g} / \mathrm{mL}$ pada panjang gelombang $428,90 \mathrm{~nm}$. Nilai absorbansi yang stabil dari hasil pencampuran larutan kuersetin dengan pereaksi alumunium klorida terjadi pada menit ke-30. Penentuan Operating time untuk fenolik dilakukan dengan membaca serapan senyawa kompleks molibdenum-tungsten konsentrasi 30 $\mu \mathrm{g} / \mathrm{mL}$ pada panjang gelombang $757,80 \mathrm{~nm}$. Absorbansi stabil dari hasil pencampuran 
larutan asam galat dengan pereaksi folinciocalteu terjadi pada menit ke-120.

\section{Penentuan Persamaan Kurva Baku}

Pembuatan kurva baku kuersetin dilakukan dengan mengukur absorbansi larutan kompleks kuersetin- $\mathrm{AlCl}_{3}$ seri konsentrasi 5, $10,15,20$ dan $25 \mu \mathrm{g} / \mathrm{mL}$ pada panjang gelombang 428,90 nm, sedangkan kurva baku asam galat dilakukan dengan mengukur absorbansi larutan kompleks molibdenumtungsten seri konsentrasi 10, 20, 30, 40, dan 50 $\mu \mathrm{g} / \mathrm{mL}$ pada panjang gelombang 757,80 $\mathrm{nm}$. Pembuatan seri konsentrasi dilakukan pada rentang tersebut untuk memperoleh absorbansi yang memenuhi kisaran absorbansi yang baik, yaitu $0,2-0,8$.

Kurva baku kuersetin dan asam galat dibuat sebanyak 3 kali replikasi. Namun dari 3 replikasi hanya dipilih satu kurva baku dengan nilai koefesien korelasi (r) yang paling mendekati angka 1. Berdasarkan hasil penentuan kurva baku kuersetin diperoleh persamaan regresi linear $\mathrm{y}=0,02001 \mathrm{x}+$ 0,10906 ( $\mathrm{x}=\mathrm{kadar}$ flavonoid total dalam $\mu \mathrm{g} / \mathrm{mL}$, $\mathrm{y}=$ absorbansi) dengan nilai koefesien korelasi $\mathrm{r}=0,99848$, sedangkan persamaan kurva baku asam galat diperoleh $\quad \mathrm{y}=0,01086 \mathrm{x}+$ 0,12030 ( $\mathrm{x}=\mathrm{kadar}$ fenolik total dalam $\mu \mathrm{g} / \mathrm{mL}$, $\mathrm{y}=$ absorbansi) dengan nilai koefesien korelasi $r=0,99808$.

\section{Penetapan Kadar Flavonoid dan Fenolik Total}

Hasil penetapan kadar flavonoid total ekstrak metanol daun beluntas dari berbagai metode ekstraksi.

Tabel 3. Analisa flavonoid dari berbagai metode

\begin{tabular}{|c|c|c|c|c|c|}
\hline $\begin{array}{l}\text { Metode } \\
\text { Ekstraksi }\end{array}$ & \multicolumn{2}{|c|}{ Nilai Absorbansi } & \multirow{2}{*}{$\begin{array}{l}\text { Pengenceran } \\
\text { (f) } \\
100 \text { kali }\end{array}$} & \multirow{2}{*}{ 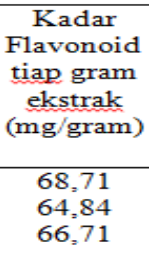 } & \multirow{2}{*}{$\begin{array}{c}\begin{array}{c}\text { Rata-rata } \\
\text { Kadar } \\
\text { Flavonoid } \\
\text { tiap gram } \\
\text { ekstrak } \\
\text { (mg/gram) }\end{array} \\
66,75\end{array}$} \\
\hline Perkolasi & $\begin{array}{l}1 . \\
2 . \\
3 .\end{array}$ & $\begin{array}{l}0,659 \\
0,628 \\
0,643\end{array}$ & & & \\
\hline Maserasi & $\begin{array}{l}1 . \\
2 . \\
3 .\end{array}$ & $\begin{array}{l}0,522 \\
0,520 \\
0,529\end{array}$ & $100 \mathrm{kali}$ & $\begin{array}{l}51,59 \\
51,34 \\
52,47\end{array}$ & 51,80 \\
\hline Sokletasi & $\begin{array}{l}1 . \\
2 . \\
3 .\end{array}$ & $\begin{array}{l}0,470 \\
0,464 \\
0,452\end{array}$ & $100 \mathrm{kali}$ & $\begin{array}{l}45,09 \\
44,34 \\
42,84\end{array}$ & 44,09 \\
\hline Refluks & $\begin{array}{l}1 . \\
2 . \\
3 .\end{array}$ & $\begin{array}{l}0,412 \\
0,406 \\
0,418\end{array}$ & $100 \mathrm{kali}$ & $\begin{array}{l}37,84 \\
37,10 \\
38,59\end{array}$ & 37,84 \\
\hline
\end{tabular}

Tabel 3 menunjukkan bahwa kadar flavonoid total pada metode perkolasi paling besar dibandingkan metode maerasi, soxhlet, dan refluks. Kadar flavonoid total ekstrak metanol daun beluntas (EMDB) dengan metode perkolasi lebih besar dibandingkan dengan maserasi walaupun hasil rendemen EMDB dari kedua metode hampir sama. Hal ini disebabkan karena perkolasi merupakan cara ekstraksi dingin dengan pergantian pelarut baru secara terus menerus sehingga tidak terjadi kejenuhan pelarut sehingga penyarian senyawa akan lebih sempurna. Metode dingin lainnya yakni maserasi tidak dilakukan pergantian pelarut secara terus menerus, sehingga mengalami kejenuhan pelarut. Kejenuhan pelarut dapat mengakibatkan flavonoid yang terkandung didalam daun beluntas tidak dapat tersari secara sempurna (Harborne, 2006).
Kadar flavonoid total EMDB dengan metode soxhlet lebih besar dibandingkan dengan refluks, begitupula dengan hasil rendemen ekstraknya. Hal ini disebabkan karena proses ekstraksi secara refluks dilakukan dengan mencampur pelarut dan simplisia dalam satu wadah dan dilakukan pemanasan secara langsung pada saat pencampuran. Hal ini menunjukkan bahwa senyawa flavonoid yang terkandung dalam EMDB memiliki sifat tidak stabil terhadap panas. Ada kemungkinan juga senyawa flavonoid tersebut rusak ketika proses pemanasan, sehingga kadar flavonoid EMDB metode refluks lebih kecil dibandingkan soxhlet.

Hasil penetapan kadar fenolik total ekstrak metanol daun beluntas dari berbagai metode ekstraksi 
Tabel 4. Kadar Fenolik dari Berbagai Metode

\begin{tabular}{|c|c|c|c|c|c|}
\hline $\begin{array}{c}\text { Metode } \\
\text { Ekstraksi }\end{array}$ & \multicolumn{2}{|c|}{ Nilai Absorbansi } & $\begin{array}{c}\text { Pengenceran } \\
\text { (f) }\end{array}$ & $\begin{array}{c}\text { Kadar } \\
\text { Fenolik tiap } \\
\text { gram } \\
\text { ekstrak } \\
(\mathrm{mg} / \mathrm{gram})\end{array}$ & $\begin{array}{c}\text { Rata-rata } \\
\text { Kadar } \\
\text { Fenolik tiap } \\
\text { gram } \\
\text { ekstrak } \\
\text { (mg/gram) }\end{array}$ \\
\hline Perkolasi & $\begin{array}{l}1 . \\
2 . \\
3 .\end{array}$ & $\begin{array}{l}0,629 \\
0,631 \\
0,625\end{array}$ & $100 \mathrm{kali}$ & $\begin{array}{l}117,10 \\
117,56 \\
116,18\end{array}$ & 116,95 \\
\hline Maserasi & $\begin{array}{l}1 . \\
2 . \\
3 .\end{array}$ & $\begin{array}{l}0,485 \\
0,483 \\
0,489\end{array}$ & $100 \mathrm{kali}$ & $\begin{array}{l}83,95 \\
83,49 \\
84,88\end{array}$ & 84,11 \\
\hline Sokletasi & $\begin{array}{l}1 . \\
2 . \\
3 .\end{array}$ & $\begin{array}{l}\mathrm{O}, 413 \\
0,422 \\
0,406\end{array}$ & $100 \mathrm{kali}$ & $\begin{array}{l}67,38 \\
69,45 \\
65,77\end{array}$ & 67,53 \\
\hline Refluks & $\begin{array}{l}1 . \\
2 . \\
3 .\end{array}$ & $\begin{array}{l}0,313 \\
0,317 \\
0,309\end{array}$ & $100 \mathrm{kali}$ & $\begin{array}{l}44,36 \\
45,28 \\
43,44\end{array}$ & 44,36 \\
\hline
\end{tabular}

Hasil penetapan kadar fenolik total menunjukkan hasil yang relatif sama seperti kadar flavonoid total yaitu metode perkolasi menghasilkan kadar fenolik total paling besar dibandingkan metode lainnya. Penelitian ini menunjukkan bahwa kandungan flavonoid total dan fenolik total dalam ekstrak metanol daun beluntas memiliki sifat tidak stabil terhadap pemanasan. Proses pemanasan baik secara langsung maupun tidak langsung sangat mempengaruhi kadar kedua senyawa tersebut dalam ekstrak.

Data kadar flavonoid dan fenolik total kemudian dianalisis secara statistik menggunakan One-Way Anova. Hasil ujinya menunjukkan bahwa kadar flavonoid dan fenolik total ekstrak metanol daun beluntas dari beberapa metode ekstraksi memiliki perbedaan bermakna dengan nilai signifikansi $<0,05$ (Lampiran 15). Uji post hoc test menggunakan uji bonferroni. Pemilihan uji bonferroni berdasarkan jumlah sampel yang digunakan dalam penelitian relatif sedikit.

Hasil uji bonferroni menunjukkan bahwa terdapat perbedaan yang bermakna diantara semua kelompok perlakuan yang artinya bahwa perbedaan metode ekstraksi ekstrak metanol daun beluntas menghasilkan kadar flavonoid dan fenolik total yang berbeda.

Hasil pengukuran kadar flavonoid dan fenolik total menunjukkan bahwa proses penyarian EMDB lebih baik dilakukan dengan cara dingin dibandingkan cara panas. Penelitian Settharaksa et al (2012) melaporkan bahwa suhu dan lamanya waktu pemanasan pada proses ekstraksi dapat berpengaruh terhadap kadar senyawa flavonoid dan fenolik yang diperoleh. Hasil penelitian ini mengindikasikan bahwa senyawa flavonoid dan fenolik dalam ekstrak metanol daun beluntas banyak yang rusak dan tidak stabil terhadap pemanasan. Suhu tinggi dan lamanya waktu pemanasan dapat merusak dan mengganggu kestabilan fragmen didalam tumbuhan sehingga berakibat berkurangnya kadar senyawa flavonoid dan fenolik dalam daun beluntas. Selain itu, jumlah pelarut dalam proses ekstraksi juga dapat mempengaruhi banyaknya kandungan metabolit sekunder yang tertarik dalam ekstrak. Perkolasi merupakan ektraksi cara dingin yang dilakukan dengan pergantian pelarut secara terus menerus sampai didapatkan perkolat yang jernih. Pelarut yang dibutuhkan dalam metode perkolasi lebih banyak dibandingkan metode maserasi, soxhlet, dan refluks. Dapat diasumsikan bahwa semakin banyak pelarut yang digunakan dalam proses ekstraksi maka jumlah senyawa yang tersari juga semakin banyak (Harborne, 1987).

Dalam penelitian sebelumnya diketahui bahwa daun beluntas memiliki berbagai bioaktivitas sebagai antioksidan, antiinflamasi, antimikroba, antinosiceptor, antituberkulosis, antiproliferasi sel kanker, antidiare, dan antitusif (Suriyaphan, 2014). Bioaktivitas tersebut diduga berkaitan dengan kandungan senyawa flavonoid dan fenoliknya. Oleh karena itu, penelitian selanjutnya diarahkan untuk menemukan senyawa aktif yang terdapat dalam ekstrak metanol daun beluntas melalui isolasi senyawa aktif flavonoid dan fenolik. Kedua senyawa aktif tersebut nantinya dapat digunakan sebagai marker (senyawa penanda) dalam proses standarisasi ekstrak.

\section{KESIMPULAN DAN SARAN \\ Kesimpulan}

Kesimpulan yang diperoleh dari penelitian ini adalah :

1. Perbedaan metode ekstraksi menghasilkan kadar flavonoid dan fenolik yang berbeda 
pada ekstrak metanol daun beluntas (Pluchea indica $\mathrm{L}$.).

2. Metode ekstraksi yang menghasilkan kadar flavonoid dan fenolik total paling besar adalah perkolasi yakni $66,75 \mathrm{mg} /$ gram ekstrak untuk flavonoid total, sedangkan kadar fenolik totalnya sebesar $116,95 \mathrm{mg} / \mathrm{gram}$ ekstrak.

\section{Saran}

Perlu dilakukan penelitian lebih lanjut tentang penemuan senyawa aktif yang terdapat dalam ekstrak metanol daun beluntas melalui isolasi senyawa flavonoid dan fenolik.

\section{UCAPAN TERIMAKASIH}

Ibu Maulita Cut Nuria, M.Sc., Apt dan Ibu Anita Dwi Puspitasari, M.Pd atas segala bimbingannya. Ibu Devi Nisa Hidayati, M.Sc., Apt dan Ibu Dewi Andini Kunti Mulangsri, M. Farm atas segala masukannya kepada penulis. Bapak, Ibu, kakak, serta keluarga, Lina, Mas Lean, Tisa Imas, Esa Wulandari, Naimi Amalia, Baiq Aryn, dan, serta kepada seluruh pihak yang telah membantu dalam penelitian dan penyusunan skripsi ini.

\section{DAFTAR PUSTAKA}

Agustiningsih, A.,Wildan, dan Mindaningsih, 2010, Optimasi Cairan Penyari Pada Pembuatan Ekstrak Daun Pandan Wangi (Pandanus amaryllifous Roxb) Secara Maserasi Terhadap Kadar Fenolik Dan Flavonoid Total, Momentum, 6, 36-41.

Ahmad, A.R., Juwita, Ratulangi, S.A.D. dan Malik, A., 2015, Penetapan Kadar Fenolik dan Flavonoid Total Ekstrak Metanol Buah dan Daun Patikala (Etlingera elatior (Jack) R.M.SM), Pharm Sci Res, 2, 1-10.

Andarwulan, N., Batari R., dan Sandrasari, D.A., 2010, Flavonoid Content and Antioxidantactivity of Vegetables from Indonesia, Food Chemical, 121, 1231 1235.

Bimakr, M., Russly, A.R., Ganjloo, A., Saleena, F., Salleh, L.M., Selamat, J., Hamid, A. dan Zaidu, I.S.M., 2011, Comparison of different extraction methods for the extraction of major bioactive flavonoid compounds from spearmint (Mentha spicata L.) leaves, Food and Bioproducts Processing, 89, 67-72.
Chang, C., Yang, M., Wen, H., dan Chern, J., 2002, Estimation of total flavonoid content in propolis by two complementary colorimetric methods, Journal of Food and Drug Analysis, 10, 178-182.

Damar, Revolta, M., dan Defny, S.W., 2014, Kandungan Flavonoid dan Aktivitas Antioksidan Total Ekstrak Metanol Daun Kayu Kapur (Melanolepsis multiglandulosa Reinch f), Jurnal Ilmiah Farmasi Universitas Sam Ratulanggi, 3, 1-11.

DepKes R.I., 1986, Sediaan Galenik, Departemen Kesehatan Republik Indonesia, Jakarta, 20, 21, 25, 27, 30.

Depkes R.I, 2006, Monografi Ekstrak Tumbuhan Obat Indonesia, Jilid 2, Direktorat Standarisasi Obat Tradisional, Kosmetik dan Produk Komplemen, Jakarta, 30, 33, 37, 40.

Emadeldin, M.K., dan Sayed, A., 2013, Phenolic Constituents and Biological Activity of the Genus pluchea, Der Pharma Chemica, 55, 109-114.

Harborne, J.B., 1987, Metode Fitokimia dan Penuntun Cara Modern Menganalisis Tumbuhan, Penerjemah Padmawinata K., dan Soediro I., ITB Press, Bandung, 4-5. 